\title{
OCCURRENCE AND DISTRIBUTION OF MOLLUSCA FAMILY TROCHIDAE AT BADI ISLAND SW-SULAWESI INDONESIA
}

\author{
M. Litaay \\ Dept of Biology, Faculty of Mathematics and Natural Science, Hasanuddin University, Campus Tamalanrea, \\ Makassar, 90245, Indonesia.e-mail: magdalenalitaay@yahoo.com
}

\begin{abstract}
The occurrence and distribution of family trochidae at Badi Island, Spermonde Archipelago off SW-Sulawesi has been studied. The line transect with combination of quadrant method was used during sampling. A transect covering $400 \mathrm{~m}^{2}$ of sampling area was applied at 1,3,5, and $7 \mathrm{~m}$ depth, respectively. Parameters such as shell length and size-class distribution were observed. Ecological parameters were also recorded during investigation. We found the presence of 11 species of trochidae at the study area. It was evident that some trochidae were common and while top shell Trochus niloticus seems to be rare. Vertical distribution among this group was uneven. The number of species decreases with increasing depth. Furthermore, high density of smaller trocha occurred at shallow water followed by a decline with changes in depth.
\end{abstract}

Keywords: Tropical trocha, Ecology and occurrence, Vertical and class-size distribution

\section{INTRODUCTION}

Family Trochidae including the economic species the top shell Trochus niloticus belongs to molluscan class gastropoda, is widely distributed in the western Indo-Pacific regions. Top shell and others trochidae are important for business, due to their nacreous shell and edible meat (Nash, 1993). Recently, this group rapidly decrease in number elsewhere (Amos and Purcell 2003; Purcel et al., 2004) not excluding in Indonesia (Dwiono et al., 1997). Among trochidae, Trochus niloticus the top shell known as "Lola" or "lola merah" or "susu bundar", is one of endangered species in Indonesia (Noerdjito and Maryanto 2001).

Previous investigations on molluscan trochidae particularly in Indonesia were on aspects such as seed production (Dwiono et al., 1997; Crowe et al., 2002), distribution of individual top shell (Nessa \& Rahman 1994; Paonganan et al. 2001), growth (Soekendarsi et al., 2001). The Spermonde water of SW-Sulawesi is known as one of marine areas that posses quite high marine biodiversity. This is probably due to the fact that the ones that is geologically stable while ecologically is very diverse. Badi Island is amongst some populated island in Spermonde with majority of its inhabitant are fishermen. The existence of Trochidae in nature is important since they are part of tropical coral reef formation. Like other reef species, their presence are influenced by the others reef species as well as the surrounding environment. Therefore, understanding the condition of occurrence of trochidae and its vertical distribution would provide additional information about its status in nature that can be of use for further study.

\section{MATERIALS AND METHODS}

Sampling was conducted at Badi waters in 1996 (119¹7'E; 045' S), an area located, approximately 12 miles SW of Makassar. Local port was situated at eastern side of the island quite highly damaged area was noticed at northern side. Sampling was carried out at western and southern part of the island. On these places, a hundred meter of line transect was made parallel to reef margin. The transect was marked at every $10 \mathrm{~m}$ where the square of $2 \times 2 \mathrm{~m}^{2}$ was straddling of the marks 
along the line. In total, $400 \mathrm{~m}^{2}$ sampling area was counted for each transect. To determine vertical distribution of throchidae, a similar method was applied at different depth of 1,3,5,7 meters depth, respectively. SQUBA was used in this study. All member of trochidae inside the square was identified, number counted, shell measured, and representative samples were collected for further investigation. Ecological parameters such as salinity, water temperature and dissolved oxygen were observed and recorded during sampling. Observation of samples included number of species and organism and shell length. Size measurements were made using a Caliper having accuracy of $0.1 \mathrm{~mm}$. Species identification was based on shell characteristics, as already applied by Dharma (1988).

\section{RESULTS}

\section{Occurrence and Density}

In totally, there are eleven species of trochidae were found at Badi waters and their occurrence and size ranges is shown in Table 1. The smallest trocha was $C$. artopurpureus $(6.9 \mathrm{~mm})$, while the biggest was $T$. niloticus $(79.85 \mathrm{~mm})$.

As seen from Table 1, distribution of trochidae seems to be related to depth. All eleven species occurred at shallowest water $(1 \mathrm{~m})$. With increasing of depth, the number of species decreases. Six species (C. conus, T. fenestratus, T. maculatus, T. niloticus, $T$. radiatus, and $T$. sacellum) existed at 3-meter depth, while $C$. conus, T. niloticus and T. sacellum were found at 5-meter depth. Both T. niloticus and $T$. sacellum are presented at all depths. It also appears, shallow water would be a convenient place to live for $C$. paradoxum; $C$. artopurpureus, J. exaperatus and T. pyramis.

Habitat at $1 \mathrm{~m}$ depth is dominated by sand, rubble and scattered live coral. There are also some algae lived in this area, which is probably part of throchidae's food. Most of trocha at this depth settle inside holes, under stones or was hidden between death corals. Habitats at three and five meter depths are coral reef, mostly branching coral such as Acropora spp and soft corals. In these areas, branching coral provides a good shelter for trochidae since it is common to find trochidae closed each other at the lower part of corals. This is probably part of feeding strategy of the animals. Trochidae is herbivorous which is having radula that helps them to scratch food at substrate. For example, young top shell prefers diatome and corraline algae for their food (Castell et al., 1996), while, adult ones prefer macro algae such as brown and red algae (Soekendarsih et al., 2001). Therefore, decreasing number of trochidae with depth relates to availability of food. However, some species have a wide vertical distribution, for example, T. niloticus and T. sacellum. For other species, it is found unusual that T. pyramis only occurred at shallow water of 1 meter while as Dharma (1988) reported that this species could be found living at several depths.

Table 1. The occurrence and size ranges of family Throchidae at different depth

\begin{tabular}{|c|c|c|c|c|c|c|c|c|c|c|}
\hline \multirow{2}{*}{ No } & \multirow{2}{*}{ Species } & \multicolumn{4}{|c|}{ Depth (m) } & \multirow{2}{*}{$\begin{array}{c}\text { Size } \\
\text { ranges } \\
(\mathrm{mm})\end{array}$} & \multicolumn{4}{|c|}{ Class size distribution (mm) } \\
\hline & & 1 & 3 & 5 & 7 & & $0-20$ & $20-40$ & $40-60$ & $60-80$ \\
\hline 1 & Cardinalis conus $\mathrm{L}$ & $\sqrt{ }$ & $\sqrt{ }$ & $\sqrt{ }$ & o & $43.2-74$ & - & - & $\mathrm{x}$ & $\mathrm{x}$ \\
\hline 2 & Chrysostoma padoxum Born & $\sqrt{ }$ & 0 & 0 & $\mathrm{O}$ & $9.1-8.5$ & $\mathrm{x}$ & - & - & - \\
\hline 3 & $\begin{array}{l}\text { Clanculus artopurpureus Gould, } \\
1948\end{array}$ & $\sqrt{ }$ & 0 & 0 & o & $6.9-8.5$ & $\mathrm{x}$ & - & - & - \\
\hline 4 & Jujubinus exaperatus & $\sqrt{ }$ & 0 & o & o & $22-31.2$ & - & $\mathrm{x}$ & - & - \\
\hline 5 & Tectus fenestratus Gmelin, 1791 & $\sqrt{ }$ & $\sqrt{ }$ & $\mathrm{O}$ & $\mathrm{O}$ & $7.5-26.1$ & $\mathrm{x}$ & $\mathrm{x}$ & - & - \\
\hline 6 & Tectus pyramis Born, 1758 & $\sqrt{ }$ & 0 & 0 & $\mathrm{O}$ & $8.3-9.1$ & $\mathrm{x}$ & - & - & - \\
\hline 7 & Trochus maculatus Linne, 1758 & $\sqrt{ }$ & $\sqrt{ }$ & o & 0 & $7.5-33.9$ & $\mathrm{x}$ & $\mathrm{x}$ & - & - \\
\hline 8 & Trochus niloticus Linne, 1767 & $\sqrt{ }$ & $\sqrt{ }$ & $\sqrt{ }$ & $\sqrt{ }$ & $10.4-79.8$ & $\mathrm{x}$ & $\mathrm{x}$ & - & - \\
\hline 9 & Trochus radiatus Gmelin, 1791 & $\sqrt{ }$ & $\sqrt{ }$ & o & $\mathrm{O}$ & $21.5-32.1$ & - & $\mathrm{x}$ & $\mathrm{x}$ & $\mathrm{x}$ \\
\hline 10 & Trochus sacellum Philippi & $\sqrt{ }$ & $\sqrt{ }$ & $\sqrt{ }$ & $\sqrt{ }$ & $9.5-29.2$ & $\mathrm{x}$ & $\mathrm{x}$ & - & - \\
\hline 11 & Trochus tubiferus Keiner & $\sqrt{ }$ & 0 & 0 & 0 & $7.35-23.2$ & $\mathrm{x}$ & $\mathrm{x}$ & - & - \\
\hline & Total number of species & 11 & 6 & 3 & 2 & & & & & \\
\hline
\end{tabular}



$\square$ C. conus
C. padoxum
$\square$ C. artopurpureus
$\square$ J. exaperatus
$\square$ T. fenestratus
- T. pyramis
- T. maculatus
$\square$ T. niloticus
T. radiatus
๑T. sacellum
$\square$ T. tubiferus

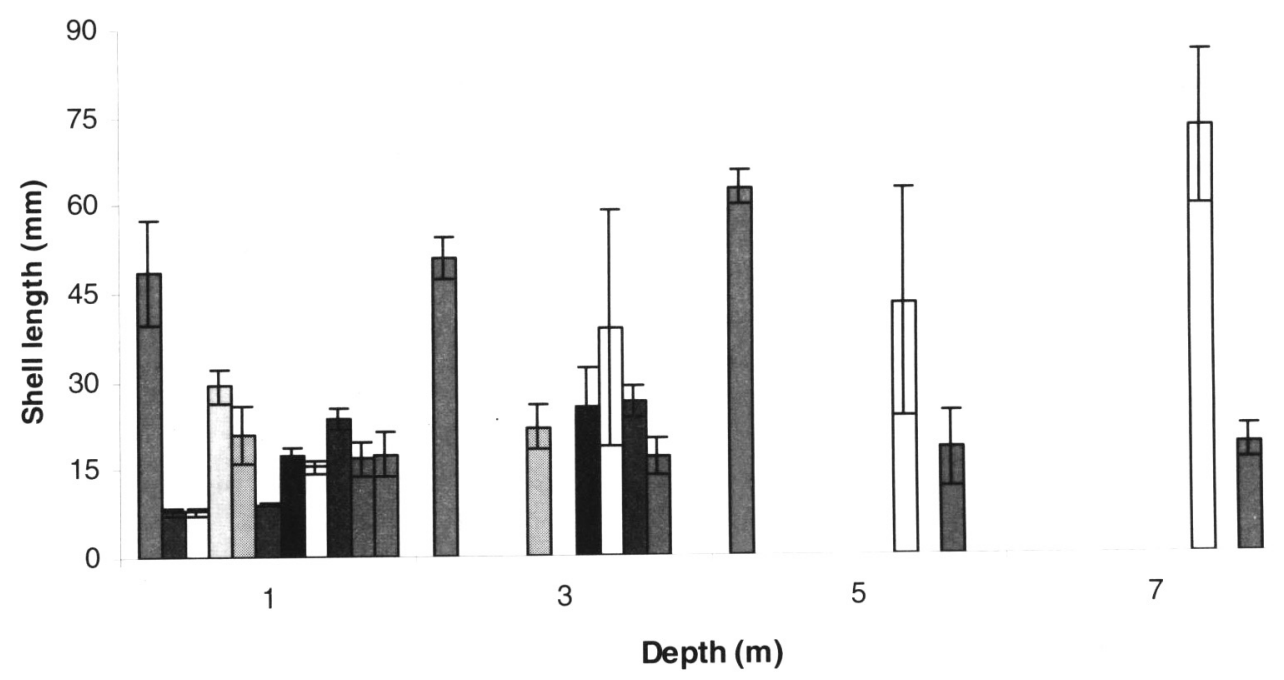

Figure 1. Distribution of shell length (mean $\pm \mathrm{sd}$ ) of family trochidae at different depth

a)

\section{Trochus niloticus}

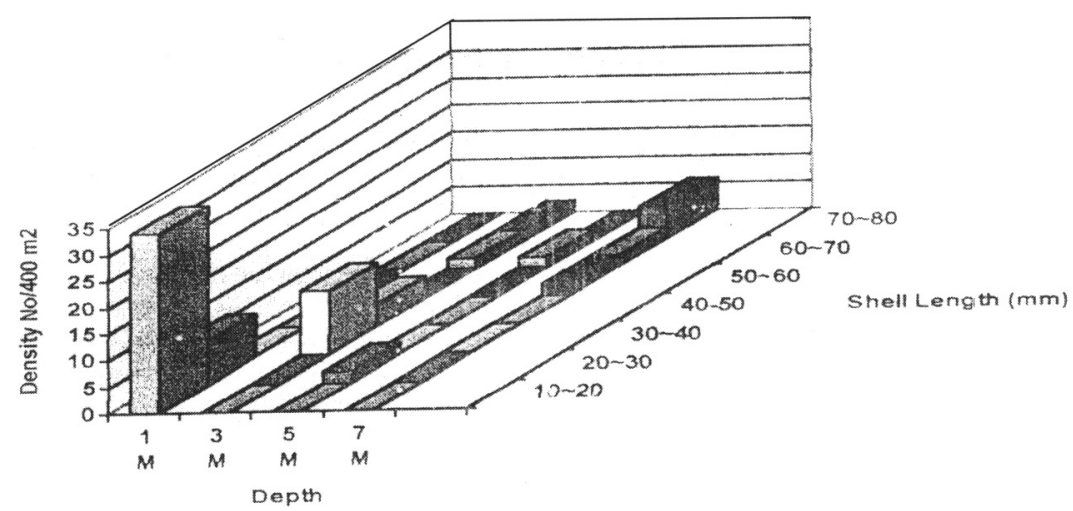

b)

\section{Trochus sacellum}

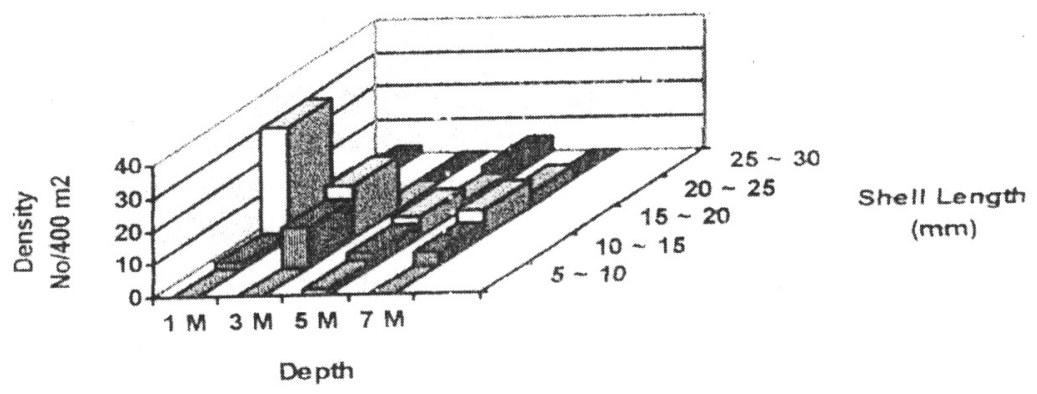

Figure 2. Class-size distribution of T. niloticus (a) and T. sacellum (b) 


\section{Size-class distribution}

Mean shell length of trochidae at different depth is shown in Figure 1. As seen from the figure, there is increase of animal's size with increasing of depth. Two species namely $T$. sacellum and $T$. niloticus present at all depth (Table 1 and Fig. 1) and their density and size-class distribution is described in Figure 2.

Of bigger trochas, size of top shell T. niloticus and C. conus increase with increasing depth (Fig. 1). However, density of the former species decreases with increasing depth (Fig. 2). Both species have a relatively bigger body size; however their population numbers are relatively small.

\section{DISCUSSION}

Previous studies indicated that juveniles of $T$. niloticus lived among the coral ruble on the intertidal reef flat where small wild juveniles $(<30$ $\mathrm{mm}$ ) were difficult to find (Helsinga et al., 1984; Smith, 1987; Kubo, 1991). They are cryptic because of their small size, as the colours of the shell are similar to those of coralline algae of the rubble on which they live (Castell et al., 1996). Study on other cryptic animals, for example, small abalones indicate that up to $70 \%$ of the population could be missed during census (Shepherd 1990; Tanaka et al., 1991).

An opposite trend is noticed for small trochidae, for instance T. sacellum, T. maculatus and $T$. radiatus. Due to their sizes, these groups might be ignored by poachers. This may be the explanation why bigger population size of smaller trocha is found at shallow water.

In the present study, bigger trocha with shell length of $42.85 \mathrm{~mm}$ and more exists at five-meter depth, and towards reef margin. Habitat preference, growth rate and ecology of trochus vary regionally (Nash, 1993). Juvenile tend to prefer hard substrata of reef flat areas (Castell, 1997) whereas adults can be found at reef crest, reef slope, but appear not to migrate far after settlement (Crowe et al., 2002). The planktonic larvae apparently settle on the outer reef flats, and juvenile may migrate to the reef margin and deeper water as they grow. This can explain the increase in size of animal with increasing of depth as shown by top shell. With rare exception, individuals of this species, of smaller than $50 \mathrm{~mm}$ are not found in water deeper than three meters (Stojkovich and Smith 1978; Smith, 1987).

The present study indicates that the occurrence and distribution pattern of trochidae in Badi waters differs among species. Of the 11 species studied, five are occurring in only $1 \mathrm{~m}$ depth, three up to 3 meter, one up to 5 meter, and two species occurred at all depths (See Table 1). In this study, ecological parameters are: salinity $34-35 \%$, temperature $28-28.5^{\circ} \mathrm{C}$, and dissolved oxygen $4-5 \mathrm{ppm}$. These values are still favorable for trochas. The latest finding indicates that the top shell was not found in Badi waters (CCRS, 2002). It seems that over fishing may be a major cause for depletion of bigger trochas especially the top shell. Therefore, the existence of bigger trocha especially the economic important ones in this area tends to be determined by human activities.

Trochus fisheries are typically artisanal or community-based, where harvesting is normally by reef walking. This trend has brought the situation that rapid depletion in wild stock occurs in many areas. In addition, the dramatic rise in global trochus demand for priced trochus shell during the last few decades are concomitant with the rise in fishing activity. Nowadays restocking and enhancement programs are in global trend in order to overcome depletion in top shell wild stock. Purcell (2004) suggested that successful restocking is depended on several factors, i.e. methods used: tiny hatchery-produced juvenile in mass numbers; larger juveniles after a period of culture in the hatchery or sea cages or adult broodstock, collected from other reefs. A Hatchery owned by Hasanuddin University which located at Barrang Lompo Island nearby Badi Island has opportunity in developing top shell aquaculture. The available facilities could be utilized to assist government with conservation program by producing mass juvenile for restocking and enhancement of top shell, other endangered species as also other important economic ones. Since operational cost for land-based hatchery is not cheap, successful long run hatchery can only be achieved through a better management program amongst stakeholders; government, hatchery owner, industry and islanders. 


\section{REFERENCES}

Amos, M.J and S.W. Purcel. 2003. Evaluation strategies for intermediate culture of Trochus niloticus (Gastropods) in sea cages for restocking. Aquaculture, 218 ( 1-4): 235-249.

Castell, L.L., W. Naviti and F. Nguyen. 1996. Detectability of cryptic juvenile Trochus niloticus Linnaeus in stock enhancement experiments. Aquaculture, 144: 91-101.

CCRS Unhas (Centre for Coral Reef Studies, Hasanuddin University). (2002). Final Report, Ecological Assessment of Spermonde Archipelago, Pangkep Regency South Sulawesi.

Crowe, T.P., K.A. Lee, M.J.Amos, J. Dangeubun, S.A.P. Dwiono, P.C. Manuputty, F. N'guyen, K. Pakoa and J. Tetelepta. 2002. Experimental evaluation of the use oh hatchery-reared juvenile to enhance stocks of the topshell Trochus niloticus in Australia, Indonesia and Vanuatu. Aquaculture, 206 (3-3): 175197.

Dharma, B. 1988. Indonesian Shells. PT. Sarana Graha. Jakarta. 32-37.

Dwiono, S.A.P., P.C. Makatipu and Pradina. 1997. A hatchey for the topshell (T. niloticus) in Eastern Indonesia. In: Trochus: Status, Hatchery Practice and Nutrition. ACIAR Proceeding no 79:33-37.

Helsinga, G.A., O. Orak and M. Ngiramengior. 1984. Coral reef sanctuaries. For trochus shell. Mar. Fish. Rev., 46: $73-80$.

Kubo, H. 1991. Study on seed releasing of trochus. Okinawa Prefectural Fisheries Experimental Station Report (in Japanese, English translation by Jiro Isa, FAO / SPADP, Suva Fiji) 21 pp.

Nash, W.J. 1993. Trochus. In: 'Nearshore Marine Resources of the South Pacific'. (Eds A. Wright and L. Hill) pp. 452-95. Honiara, Fiji, IPS, FFA, International Centre for Ocean Development.
Nessa, H.M. and A. Rahman. 1994. Study on reproduction, distribution and density of Trochus spp and Tectus spp in National Park of Taka Bone Rate. Proc. Sem. Re. PSL. Hasanuddin University 1993/1994: 95-106.

Noerdjito, M. and I. Maryanto. 2001. Jenis-Jenis Hayati yang Dilindungi Perundang - undangan Indonesia. Cetakan kedua. Balitbang Zoologi. Bogor.

Purcell, S. 2004. Management options for restocked trochus fisheries. In: Stock Enhancement and Sea Ranching Develoments, Pitfalls and Opportunitioes. Leber, K.M., Kitada, S., Blankenship, H.L. \& Svasand, T. eds. Blackwell Publishing. Pp. 233-243.

Purcell, S.W, M.J. Amos and K. Pakoa. 2004. Released of cultured sub-adult Trochus niloticus generate broodstock for fishery replenishment in Vanuatu. Fish. Res., 67(3): 329-333.

Shepherd, S.A. 1990. Studies on southern Australian abalone (Genus: Haliotis). XII. Long-term recruitment and mortality dynamics of an unfish population. Aust. J. Mar. Freshwater Res., 33: 265 -272 .

Smith, B.D. (1987). Growth rate, distribution and abundance of the introduced topshell Trochus niloticus Linneaus on Guam. Marina Island. Bull. of Mar. Sci., 41(2): 466-174.

Soekendarsih, E., M.I Djawad and Y.Paonganan. 2001. Growth rate of Trochus niloticus L. Fed on four species of benthic marine macrolagae. Phuket Mar. Spec Publ., 25(1):135-137.

Stojokovich, J.O. and B.D. Smith. 1978. Survey of edible marine shellfish and sea urchin on the reef of Guam. Guam Dep. Agricul. Wildlife Resources Div. Tech. Rep., 2: 2-65.

Tanaka, E., H. Yamakawa, S. Yamada, M. Nonaka and A Hasegawa. 1991. A method for estimating mortality rate and divers' sighting rate for tagged abalones. Nippon Suisan Gakkaishi. 57: 189-194. 